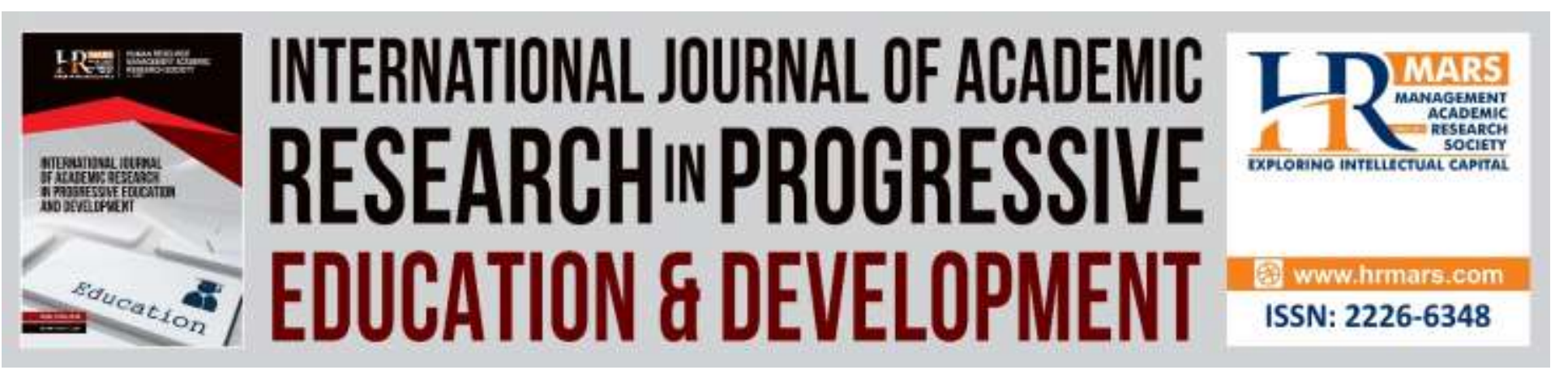

\title{
Water Sustainability: Water Usage Audit and Conservation Awareness among Students in Universiti Sains Malaysia
}

Siti Fairuz Mohd Radzi, Mohd Sayuti Hassan, Nur Izzati Ibrahim, Lim Lek Ming, Yeow Cher Yuin, Fatini Nurizzati Mat Kamal, Nurul Munirah Razali, Khaula Annisa, Suhana Mohd Zain, Syazana Morbrak Ali, Kaviratna Vijayan, and Nor Syahirah Kamarulzaman

To Link this Article: http://dx.doi.org/10.6007/IJARPED/v8-i2/6127

DOI: 10.6007/IJARPED/v8-i2/6127

Received: 11 Jan 2019, Revised: 20 Feb 2019, Accepted: 01 March 2019

Published Online: 27 March 2019

In-Text Citation: (Radzi et al., 2019)

To Cite this Article: Radzi, S. F. M., Hassan, M. S., Ibrahim, N. I., Ming, L. L., Yuin, Y. C., Kamal, F. N. M., ... Kamarulzaman, N. S. (2019). Water Sustainability: Water Usage Audit and Conservation Awareness among Students in Universiti Sains Malaysia. International Journal of Academic Research in Progressive Education and Development, 8(2), 457-471.

Copyright: (C) 2019 The Author(s)

Published by Human Resource Management Academic Research Society (www.hrmars.com)

This article is published under the Creative Commons Attribution (CC BY 4.0) license. Anyone may reproduce, distribute, translate and create derivative works of this article (for both commercial and non-commercial purposes), subject to full attribution to the original publication and authors. The full terms of this license may be seen at: http://creativecommons.org/licences/by/4.0/legalcode

Vol. 8(2) 2019, Pg. 457 - 471

http://hrmars.com/index.php/pages/detail/IJARPED

JOURNAL HOMEPAGE

Full Terms \& Conditions of access and use can be found at http://hrmars.com/index.php/pages/detail/publication-ethics 


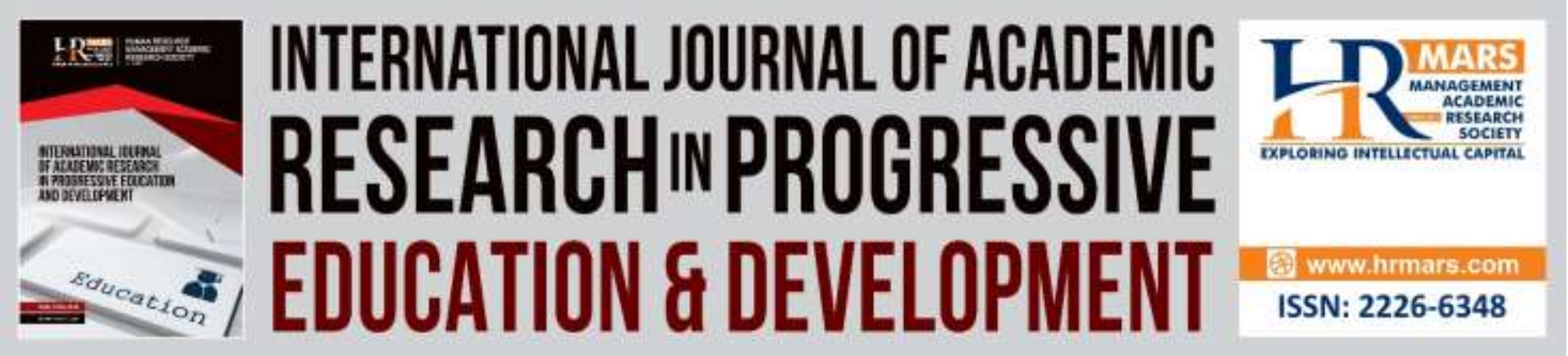

\title{
Water Sustainability: Water Usage Audit and Conservation Awareness among Students in Universiti Sains Malaysia
}

Siti Fairuz Mohd Radzia ${ }^{a}$ Mohd Sayuti Hassan, Nur Izzati Ibrahim, Lim Lek Ming, Yeow Cher Yuin, Fatini Nurizzati Mat Kamal, Nurul Munirah Razali, Khaula Annisa, Suhana Mohd Zain, Syazana Morbrak Ali, Kaviratna Vijayan, and Nor Syahirah Kamarulzaman Centre for Global Sustainability Studies, Universiti Sains Malaysia, Penang, Malaysia.

Email: afairuzradzi@usm.my

\begin{abstract}
Water, a chemical substance that is vital to sustain living things. According to some popular researches, human being can starve without food for up to 21 days but can only live up to three days without water. While the supply seems abundant, water is a limited resource, particularly the fresh potable water which is most fundamental to human survival. Water conservation is imperative to solve global water shortage problem that has become more rampant nowadays. Moreover, with the unpredictable climate change, it is crucial to conserve water before it becomes more severe to treat which in turn might leave the future generation with a great deal of dilemma. This research aims to assess water consumption and water conservation awareness among students who stay in USM hostels. Two methods have been used to conduct the research; observation and measurement of water reading in two hostel buildings which consist of nine hostel blocks in total, and distribution of a set of questionnaire to students in USM who stay in USM hostels. Recommendations on water conservation awareness are addressed accordingly.

Keywords: Water Consumption, Water Sustainability, Water Conservation, Water Management, Sustainability Awareness

\section{Introduction}

Issues related to the imbalance of water demand and supply remains rampant in many places. According to Fresh Water Watch from Earth Watch Institute (2017), approximately 97\% of the world's water is salty and undrinkable; $2.5 \%$ of water on Earth is fresh water, but only $1 \%$ of the portion is available for human's consumption. In Malaysia, approximately $97 \%$ of water resources
\end{abstract}


come from surface water and the remaining 3\% comes from groundwater. Since a few months ago, the water level in some major dams in Selangor such as in Tasik Subang and Sungai Selangor showed a significant increase of water capacity. It is without doubt that the water supply from those major dams is sufficient to accommodate the community for the next few years. However, it is crucial for Malaysians to conserve water, despite the increment of water capacity because water is a limited resource that will perish one day. In 2013, the average water consumption of Malaysians was 210 litres per day. Howbeit, in 2014, the average consumption of water has increased by 2 litres to 212 litres which is equivalent to 141 bottles of water (1.5 litres per bottle) a day for each person. Only $30 \%$ of the water consumption is used for vital activities such as cooking and drinking water and the rest of it is used for other purposes such as car washing, pool cleaning, and clothes washing (Abdullah, 2015).

Water consumption rate in Malaysia accelerates beyond the rate recommended by the World Health Organization (WHO) which is 165 litres per day. Based on the Malaysia Water Industry Guide 2014, Penang recorded the highest rate of water consumption in 2013 with 296 litres of total consumption per day. On the other hand, Sabah recorded the lowest water consumption with 190 litres of water consumption per day. The Minister of Energy, Green Technology and Water, Datuk Seri Panglima Dr Maximus Johnity Ongkili stated that according to the Domestic Water Consumption Study, Malaysians over-consume an average of 226 litres of water per day as compared to Singapore and Thailand with 155 litres and 90 litres of water consumption per day respectively. He also stated that the over consumption of water by Malaysians exceeds other major countries including United States of America and Australia (Bernama, 2016). Meanwhile, the per capita water consumption in USM is 120,000 litres/capita/year (Icy) or 329 litres/capita/day (Ipcd) in 2012. Sadly, the water consumption rate exceeds beyond the industry benchmarks rate for educational institutions which is 144 Ipcd which put USM's water usage 2.28 times above the benchmark.

A research has been conducted to study and analyse the level of water consumption for laundry activity in two hostels in Universiti Sains Malaysia; Desasiswa Aman Damai and Desasiswa Bakti Permai to examine the level of water consumption among student in USM. Each hostel has its own laundry room in several designated blocks. These laundry rooms are the main focal point for this research because they are considered as the main source of water consumption by the students. In addition, most students in USM prefer to wash their clothes by using washing machines that are provided by the hostel management with minimal charges, rather than washing by hand, due to their tight schedule. The reading of water consumption at the hostels' laundry rooms is recorded every day from 9 am to 9 pm for two consecutive weeks. Other than that, water conservation awareness among students is studied through the analysis of questionnaire survey which has been distributed to 214 students who stay in USM hostels. 
INTERNATIONAL JOURNAL OF ACADEMIC RESEARCH IN PROGRESSIVE EDUCATION AND DEVELOPMENT

Vol. 8, No. 2, 2019, E-ISSN: 2226-6348 @ 2019 HRMARS

\section{Water Issues in Penang}

Water, which covers 71\% of the Earth's surface (USGS, 2016) is vital for all known forms of life on Earth. However, most of water available on Earth is salt water which could only be consumed by human being and other living things after going through desalination process which is costly. On the Earth, $96.5 \%$ of the planet's crust water is found in seas and oceans, $1.7 \%$ in groundwater, $1.7 \%$ in glaciers and the ice caps of Antarctica and Greenland, a small fraction in other large water bodies, and $0.001 \%$ is found in the air as vapor, clouds (formed of ice and liquid water suspended in air), and precipitation (White,1993). Only $2.5 \%$ of this water is fresh water, and $98.8 \%$ of that water is in ice and groundwater. Less than $0.3 \%$ of all fresh water is found in rivers, lakes, and the atmosphere, and an even smaller amount of the Earth's fresh water $(0.003 \%)$ is contained within biological bodies and manufactured products. Despite its abundance, water is a limited resource and would go scarce if the human's daily water consumption goes beyond what is recommended. United Nations has stressed the importance of clean water in its agenda, 17 Sustainable Development Goals (17 SDGs) in which one of the goals, Goal 6, intends to ensure availability and sustainable management of water and sanitation for all (United Nations, n.d). Thus, water conservation is important to address global water scarcity problem.

Penang, a state located in the northern part of Malaysia, receives most of its water supply (approximately 80\%) from its neighbouring state, Kedah which is from Muda River. One of the main reasons for the high water consumption is due to the cost of water in Penang. Based on Figure 1, consumers in Penang only pay RM0.32 (about USD 0.077) for the first 35,000 litres per month, which is lower than the national average, RM0.70 and the cheapest in the country as compared to other states such as Johor with the highest water tariff in Malaysia, RM 1.31 (USD 0.32). Furthermore, in 2016 only, the water consumption for domestic use in Penang was more than the water consumption for business use; factories, hotels, and other businesses combined.

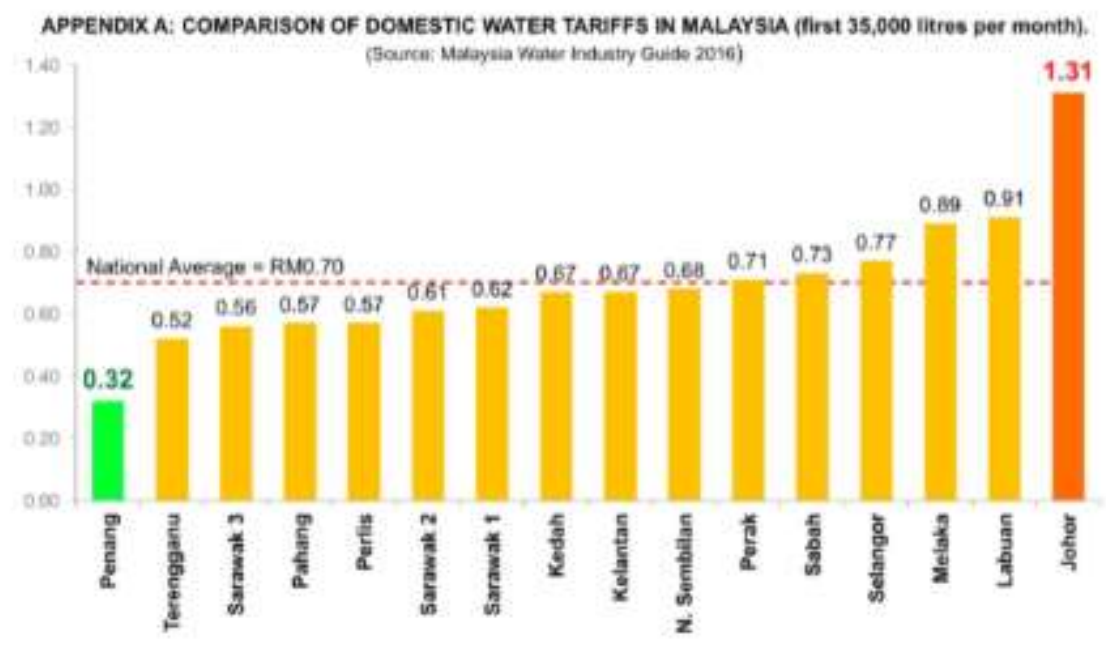

Figure 1 Domestic Water Tariff in Malaysia (Source: Penang Water Supply Corporation, 2017) 
INTERNATIONAL JOURNAL OF ACADEMIC RESEARCH IN PROGRESSIVE EDUCATION AND DEVELOPMENT

Vol. 8, No. 2, 2019, E-ISSN: 2226-6348 @ 2019 HRMARS

Penang Water Supply Corporation, a corporation that manages and provides water in Penang, has urged the Penang state government to increase the water tariff as one of the ways to reduce water wastage among people in Penang (Penang Water Supply Corporation, 2017). The then chief minister of Penang has urged the people in Penang to use water efficiently despite the cheap cost and easy access of water in Penang as compared to other states in Malaysia. Thus, to help the state government in conserving water for a sustainable tomorrow in Penang, this study has been carried out to investigate the amount of water used by student and their awareness with regard to water conservation.

\section{Water Consumption in USM Hostels}

USM has taken several initiatives to incorporate SDGs in all of its aspects within the campus environment. USM strives to be the benchmarks for best practices in water management research and related programmes in Malaysia through SDG's Goal 6 implementation. One of the objectives to realize SDGs' Goal 6 is to strive for zero waste in the university's water usage and to continuously reduce the university' production of waste water. In order to achieve the objective, several action plans have been outlined as follows:

Assess water usage for each school, centre, and hostel. Conduct water audit at all buildings within the campus. Identify inefficiencies and opportunities for water savings. Install water meters at each building. Establish a 'water saving monitoring' committee.

Rainwater harvest for daily usage such as for gardening and washing.

Recycle gray water for gardening.

Replace single flush system with dual flush system.

Encourage participation from students, staff, and vendors.

(USM Sustainability Committee, n.d).

To help the university to achieve the objectives as well as state government in reducing the water consumption, this research focused on assessing students' water consumption at laundry rooms in 9 hostel blocks. Based on the preliminary survey, it is found that $75 \%$ of students in the hostels use washing machine to wash their clothes. Washing machine consumes more water than that of using hand washing due to non-adjustable water level settings. Observation and quantitative measures are performed systemically to observe and record the number of washing machines installed and the reading of water metres at the hostel blocks. The data collection activity was performed for two consecutive weeks from 13 April to 27 April 2017. All data collected was recorded and documented accordingly. Figure 2 illustrates the location of laundry rooms in the blocks. Table 1 presents the number of washing machines available in each laundry room. 
INTERNATIONAL JOURNAL OF ACADEMIC RESEARCH IN PROGRESSIVE EDUCATION AND DEVELOPMENT

Vol. 8, No. 2, 2019, E-ISSN: 2226-6348 @ 2019 HRMARS

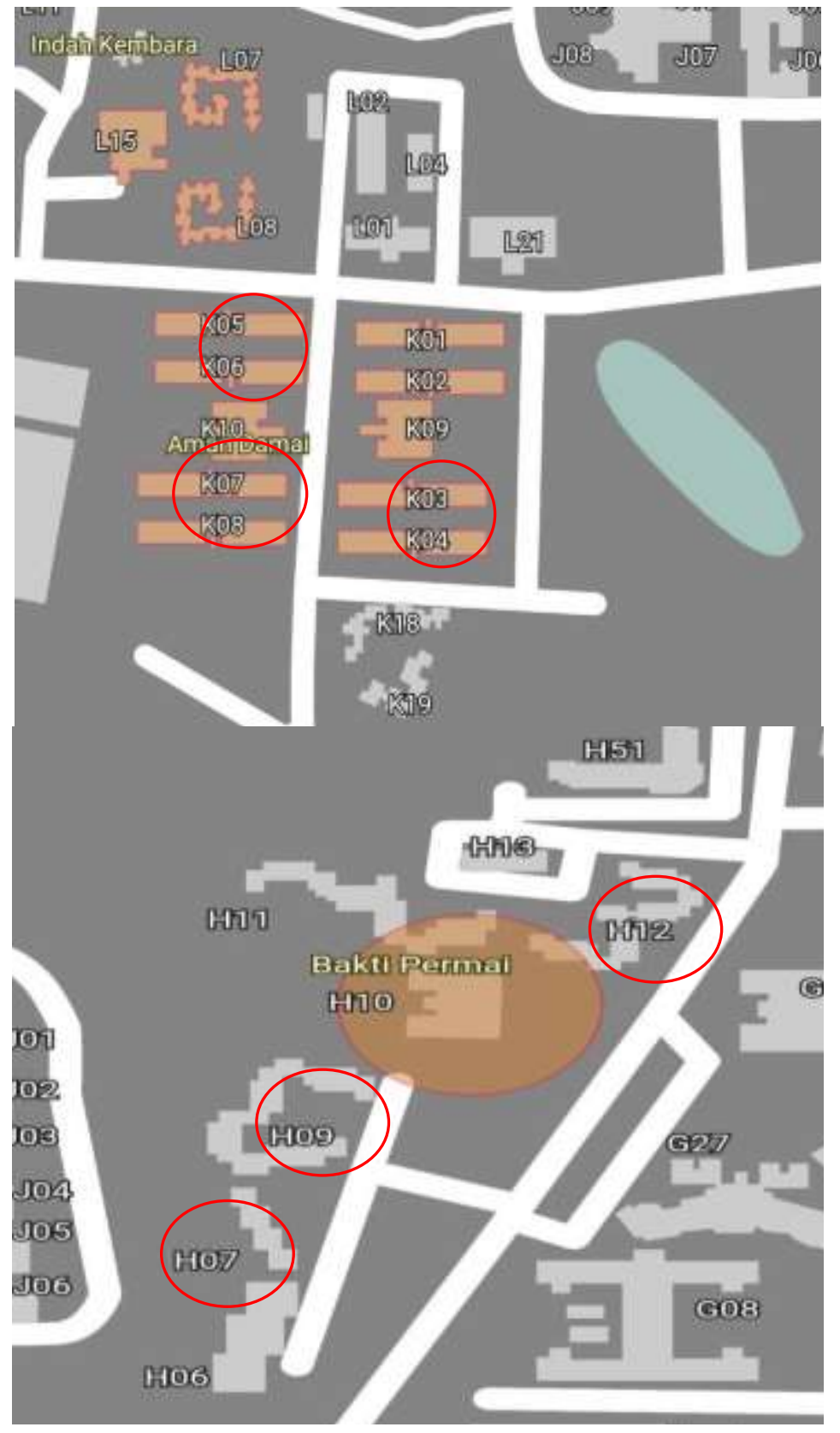

Figure 2 Mapping of Laundry Rooms in USM Hostel Blocks 
INTERNATIONAL JOURNAL OF ACADEMIC RESEARCH IN PROGRESSIVE EDUCATION AND DEVELOPMENT

Vol. 8, No. 2, 2019, E-ISSN: 2226-6348 C 2019 HRMARS

\begin{tabular}{cc} 
Block & Number of washing machine \\
\hline K03 & 1 \\
\hline K04 & 1 \\
\hline K05 & 1 \\
\hline K06 & 1 \\
\hline K07 & 1 \\
\hline K08 & 1 \\
\hline H06 & 3 \\
\hline H09 & 3 \\
\hline H12 & 3 \\
\hline Total & $\mathbf{1 5}$
\end{tabular}

Table 1 Number of washing machines available at nine hostel blocks in USM

\section{Method}

A one-week observation and measurement of water reading have been conducted in nine hostel blocks in USM. The reading of how much water has been used for washing clothes activity in the laundry rooms was collected by measuring the changes of water metre reading in each laundry room. The reading were continuously measured and recorded daily at three sessions: morning $(9$ am), afternoon (1 pm), and evening (9 pm) to ensure that data accuracy is met. After two weeks of measuring and monitoring process, all data with regard to water consumption at the laundry rooms in each block was recorded and presented in the Results Section.

A one-to-one survey on water consumption and conservation awareness was constructed. The survey contained 28 questions which consisted of 5 demographic questions and 23 questions about washing machine usage in the selected hostels and water saving awareness. The survey was distributed randomly to students in USM who stay in USM hostels.

\section{Results}

The data collection for week 1 started from 13 to 19 April 2017; in the morning, evening, and at night. Based on Table 2, the highest reading of the day came from KO7 with 15,096 litre and HO6 with 4,107, 20,151, 8,537, 3,019, 8,318, 5,785 litre of water consumption. Overall, the hostels used a total of 154,492 litre of water for week 1 . A graph chart of water consumption level in the laundry rooms for the first week is plotted and illustrated in Figure 3. 
INTERNATIONAL JOURNAL OF ACADEMIC RESEARCH IN PROGRESSIVE EDUCATION AND DEVELOPMENT

Vol. 8, No. 2, 2019, E-ISSN: 2226-6348 @ 2019 HRMARS

\begin{tabular}{crrrrrrrr}
\multicolumn{8}{c}{ AMOUNT OF WATER CONSUMPTION (LITRE)/DAY } & \multicolumn{1}{c}{ TOTAL } \\
BLOC & \multicolumn{1}{c}{$13 / 4$} & \multicolumn{1}{c}{$14 / 4$} & \multicolumn{1}{c}{$15 / 4$} & $16 / 4$ & $17 / 4$ & $18 / 4$ & $19 / 4$ & (LITRE/WEEK) \\
K & \multicolumn{1}{c}{} & & & & & & & \\
K03 & 3,380 & 1,917 & 444 & 1,537 & 1,211 & 1,629 & 790 & 10,908 \\
K04 & 1,688 & 2,265 & 3,579 & 1,011 & 1,026 & 645 & 366 & 10,580 \\
K05 & 4,616 & 2,020 & 2,521 & 1,318 & 1,524 & 2,164 & 944 & 15,107 \\
K06 & 3,969 & 975 & 2,329 & 1,457 & 1,289 & 669 & 2,090 & 12,778 \\
K07 & 15,096 & 2,224 & 1,961 & 1,597 & 290 & 178 & 816 & 22,162 \\
K08 & 6,446 & 309 & 1,302 & 1,158 & 2,676 & 1,548 & 1,138 & 14,577 \\
H06 & 5,790 & 4,107 & 20,151 & 8,537 & 3,019 & 8,318 & 5,785 & 5,5707 \\
H09 & 1,562 & 568 & 1,440 & 591 & 1,403 & 953 & 956 & 7,473 \\
H012 & 0 & 0 & 1,283 & 1,689 & 747 & 481 & 1,000 & 5,200 \\
& & & & & & TOTAL ALL & 154,492
\end{tabular}

Table 2 Water Consumption at Laundry Rooms for Week 1

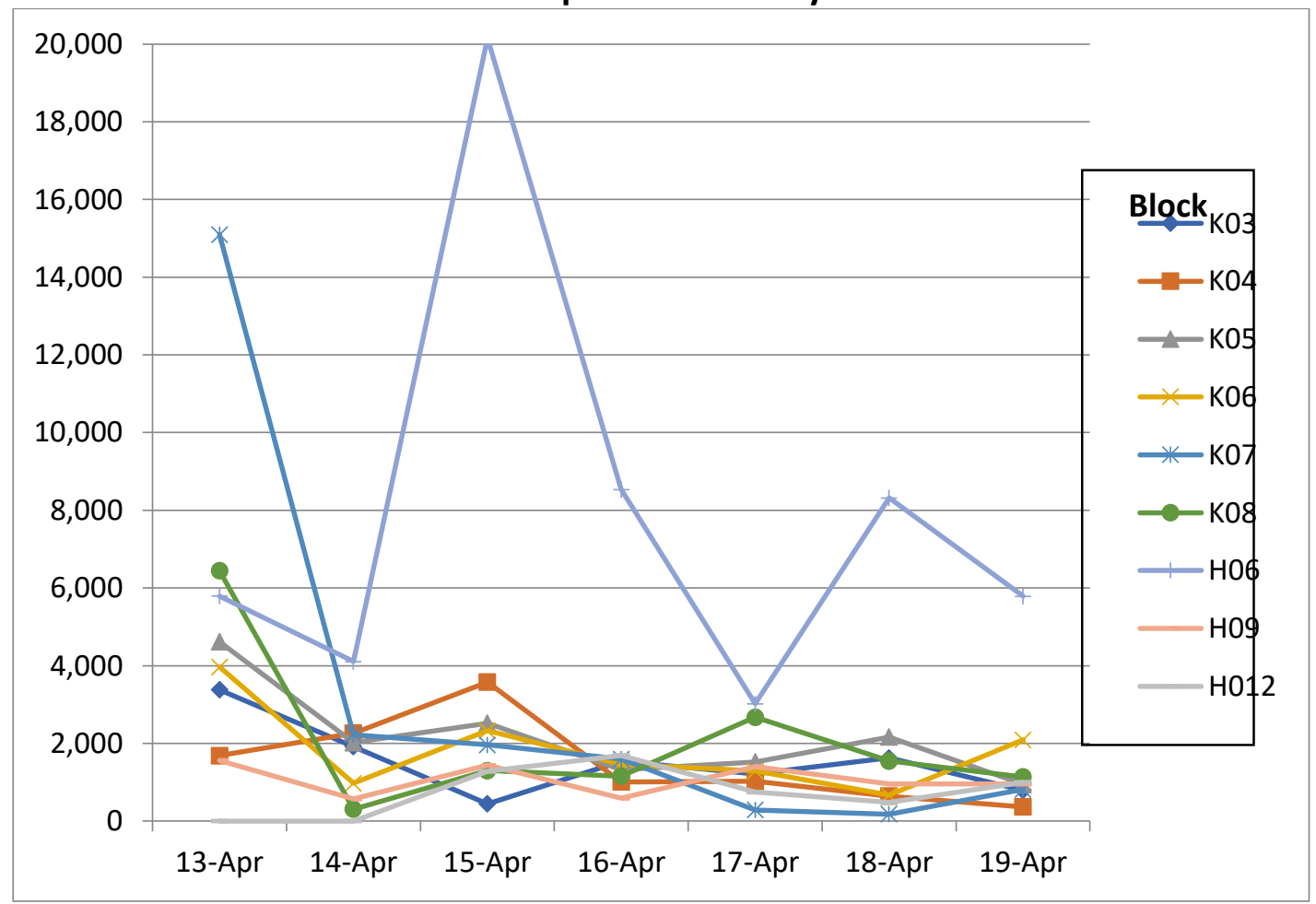

Figure 3 Graph of Water Consumption at Laundry Rooms for Week 1

Figure 3 illustrates the water consumption reading in each block for seven consecutive days in Week 1. Based on the graph, Block HO6 recorded the highest water consumption reading with 20,151 litre on 15 April 2017. Based on the observation, the reason behind the drastic increase of water consumption in the laundry room on the said day is because most students would wash their clothes on weekends. 
INTERNATIONAL JOURNAL OF ACADEMIC RESEARCH IN PROGRESSIVE EDUCATION AND DEVELOPMENT

Vol. 8, No. 2, 2019, E-ISSN: 2226-6348@ 2019 HRMARS

The data collection for week 2 started from 20 to 26 April 2017; in the morning, evening, and at night. Based on Table 3, the highest reading of the day is from building $\mathrm{HOC}$ with 7,808, 7,735, 7,881, 10,673, and 9,037, litre, K05 with 45,793 litre, and K08 with 32,562 litre of water consumption. Overall, the hostels used a total of 246,802 litre of water for week 2 to wash clothes using washing machines. A graph chart of water consumption level at laundry rooms in the hostel blocks for the second week is plotted and illustrated in Figure 4.

\begin{tabular}{crrrrrrrr} 
& \multicolumn{1}{c}{ AMOUNT OF WATER CONSUMPTION } & (LITRE)/DAY & \multicolumn{1}{c}{ TOTAL } \\
BLOCK & $20 / 4$ & $21 / 4$ & $22 / 4$ & $23 / 4$ & $24 / 4$ & $25 / 4$ & $26 / 4$ & (LITRE/WEEK) \\
K03 & 944 & 2,348 & 3,470 & 2,526 & 1,280 & 432 & 1,090 & 12,090 \\
K04 & 828 & 3,405 & 733 & 1,633 & 2,476 & 1,952 & 1,419 & 12,446 \\
K05 & 1,499 & 2,709 & 2,293 & 472 & 3,023 & 45,793 & 19,518 & 75,307 \\
K06 & 1,200 & 860 & 1,868 & 1,970 & 1,658 & 5,656 & 330 & 13,542 \\
K07 & 448 & 436 & 10 & 0 & 280 & 1,440 & 18,132 & 20,746 \\
K08 & 2,309 & 721 & 749 & 3,352 & 3,623 & 1,571 & 32,562 & 44,887 \\
H06 & 7,808 & 7,735 & 7,881 & 10,673 & 9,037 & 7,241 & 5,123 & 55,498 \\
H09 & 648 & 896 & 0 & 1,113 & 1,025 & 2,036 & 612 & 6,330 \\
H12 & 337 & 1,817 & 689 & 499 & 1,255 & 918 & 441 & 5,956 \\
& & & & & & & TOTAL ALL & 246,802
\end{tabular}

TABLE 3 Water Consumption at Laundry Rooms for Week 2

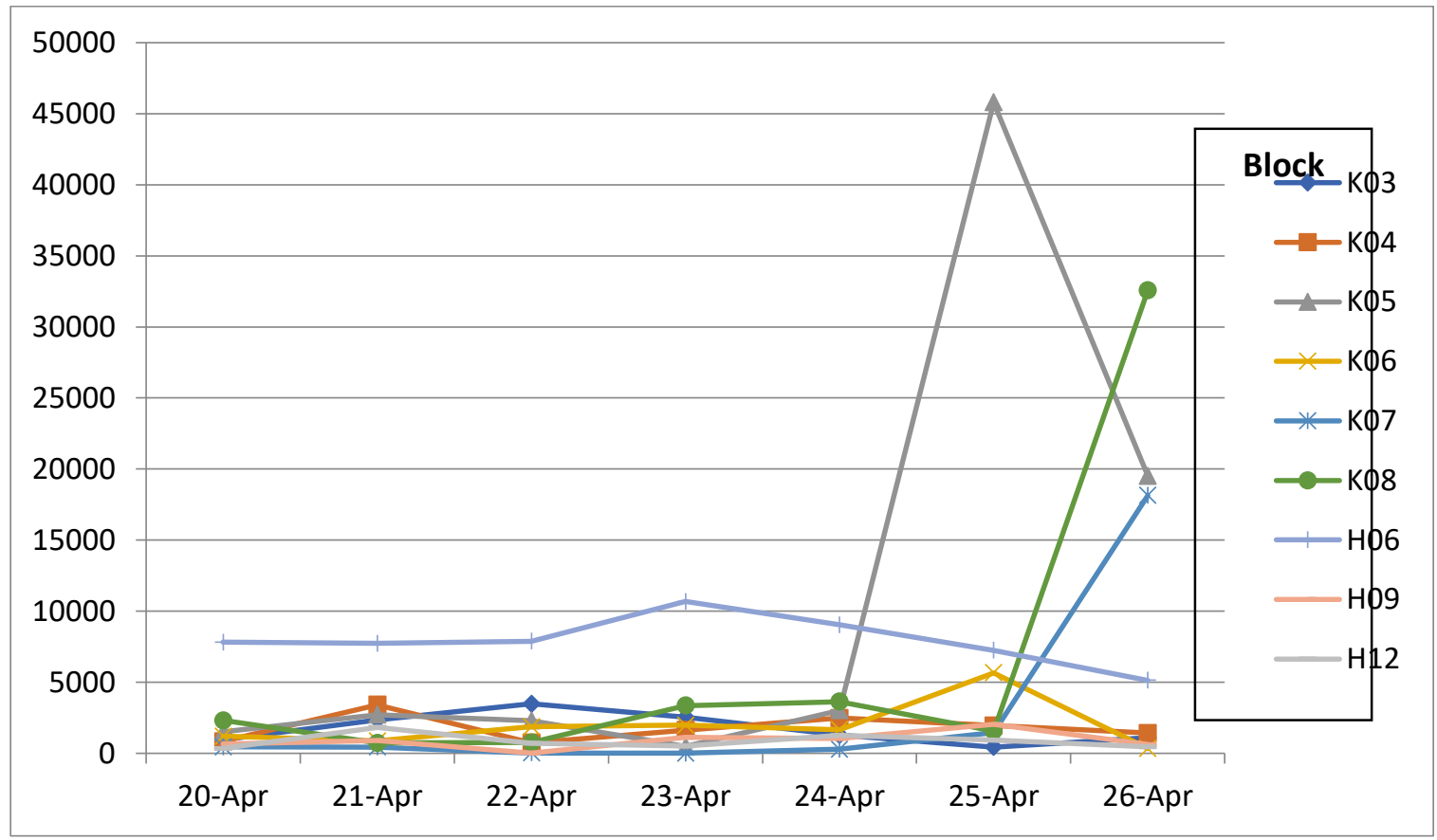

Figure 4 Graph of Water Consumption at Laundry Rooms for Week 2 
Figure 4 illustrates the water consumption reading in each block for seven consecutive days in Week 2. Based on the graph, block K05 recorded the highest water consumption reading with 45,793 litre on 25 April 2017. The reason behind the drastic increase of water consumption in the laundry room is due to the public holiday which falls on Monday, 24 April 2017. Since it was a public holiday, students would take the opportunity to go back to their hometown from Friday to Monday. They would usually keep their worn clothes for the week before washing the clothes after coming back to their hostel on Monday.

\section{Assessment of Water Saving Awareness among Student}

To assess the awareness on water saving practices among USM students, a set of survey form with multiple choice answers was prepared and distributed and 214 students who stay in USM hostels answered the survey. Based on the questionnaire answered by the respondents, an analysis was conducted to analyse the respondents' understanding their level of water consumption and conservation awareness. The questionnaire consisted of two main sections, Section 1 and Section 2 , which inquired the respondents about washing machine usage and water conservation practices respectively. Table 4 shows washing machine usage questions and responses in percentage.

\section{Question}

1. How often you wash your clothes using hostel's washing machine in a week?

2. How many clothes would you load into the washing machine per session?

3. Do you share with other people when you use the washing machine?

\section{If yes, how many} people do you share with?

\section{Percentage of Response (\%)}

Once Twice Three Times

66

22

7

5

\section{More than}

three times

$\begin{array}{cccc}\text { 5-10 clothes } & \text { 11-14 clothes } & \text { 15-19 clothes } & \\ 26.8 & 19.6 & 26.8 & 26.8 \\ \text { Yes } & \text { No above } \\ & & \\ 8 & 92\end{array}$

Share with 3 persons

Share with 2 person

Share with 1 person

80.6

17.1

2.4 
5. Does washing machine consume more water than

hand washing

method?

6. Do you agree with

Agree

Disagree

the following

statement?

Washing clothes

manually (by hand)

will save more water

than that of washing

machine.

Table 4 Section 1: Washing Machine Usage Questions and Response

Table 4 shows washing machine usage questions and responses in percentage. The section consisted of 6 multiple questions, which inquired students on their washing machine usage.

\section{Question}

1. Are you concerned about the importance of conserving water?

2. Why aren't some people aware of the importance of water conservation?

3. Which one of the following is your habit while brushing your teeth?

4. Which of the following describe your habit?
Percentage of Response (\%)
Yes

96

$$
\begin{gathered}
\text { Lack of } \\
\text { awareness }
\end{gathered}
$$

50

$$
\begin{aligned}
& \text { Water subsidies by } \\
& \text { the government }
\end{aligned}
$$

6
Malaysia does not experience any serious water crisis (drought)

44

$\begin{array}{ccccc}\begin{array}{c}\text { Turn off } \\ \text { the tap }\end{array} & \begin{array}{c}\text { Leave } \\ \text { the tap } \\ \text { on }\end{array} & \begin{array}{c}\text { Either turn off or } \\ \text { turn on the tap. } \\ \text { It depends. }\end{array} & \begin{array}{c}\text { Use a glass } \\ \text { of water }\end{array} & \text { Other } \\ 30 & 22 & 38 & 10 & 0\end{array}$

Turn off the Leave the tap tap while running while brushing teeth brushing teeth machine only machine only 
when it is fully

loaded

30 when it is not

fully loaded

22

Posters

8

64

2
4

Others
6. Do you think that water wastage is a serious problem?

7. Do you inform your family or friends about the importance of water conservation?

8. Do you think that practising Go-Green habits in your daily life could contribute positively to water conservation?

9. Have you ever participated in any water conservation programmes/activities?

\section{Books or}

14
12

Yes

88

Yes

70

Yes

No

92

8

Yes

54
12

30

No

No

Table 5 Section 2: Water Conservation Practices Questions and Responses

Table 5 shows the questions and percentage of response for Section 2. The section consists of 9 multiple questions, which inquire students on their practices towards water conservation.

\section{Discussion \& Recommendation}

Based on the findings collected through observation which has been conducted for two consecutive weeks and surveys distributed to respondents, the research found that, on average, more than 28, 000 litres of water have been used for cloth washing alone per day. Most of the respondents (82\%) wash their clothes using washing machine and out of the number, only $8 \%$ of them share the loads with their friends. This practice is not practical and would increase water wastage because if the students only wash a small load of clothes, the washing machine would still consume a lot of water to clean the loads. Based on the Consumer Reports, it is found that most 
conventional top-load washing machines use approximately 19 gallons of water to wash an average load, not per kg of load (Janeway, 2017). Thus, sharing loads with friends is one of the good ideas to be practised in order to utilize the washing machine effectively. Almost half of the respondents are aware of the impact of washing machine usage to water wastage. Even though they are aware that washing the clothes manually by hand could help to preserve more water, but due to the lack of time and tight schedules, washing machine is the best choice because it is more time-efficient and hassle free.

Furthermore, based on the findings, the highest record of water consumption in the hostels' laundry rooms for the first week is in H06 which is located at Desasiswa Bakti Permai, with 20,151 litres of water spent on 15 April 2017 (Saturday). It can be assumed the increase of water consumption in the laundry rooms at $\mathrm{HO6}$ is because most of the students wash their clothes on weekends. Meanwhile on the second week, the highest water metre reading is in K05, located in Desasiswa Aman Damai with 45,793 litres of water spent on 25 April 2017. Due to the public holiday on the day before (24 April 2017), there is a high possibility that a lot of students who returned from the three-day holiday washed their clothes in large bundles on the next day (25 April 2017). From the data, the lowest amount of water consumption is 0 litre as some washing machines in $\mathrm{H} 12, \mathrm{H} 09$, and K09 does not function well.

Based on the analysis of the survey, several recommendations are suggested to the university management in order to reduce water consumption from the use of washing machine. It can be suggested that the front load washing machine should be used as it performs better in term of saving water than a top load washing machine (Nagappan and Mathews, 2015) which has been used in all hostels in USM. It is hoped that USM would consider changing the washing machine type to front load or high efficiency top-load washing machine in the near future as a way to conserve water. Although both types of washing machines are more expensive, they could help the user to conserve water better than the conventional washing machine. Based on the survey conducted to USM students, most of the respondents strongly suggest that water conservation awareness programmes should be conducted and emphasized more in each hostel, school, and centre to educate USM community to conserve water. One of the awareness programmes that can be conducted in USM is 'USM Water Day' which is similar to 'World Water Day' introduced by the United Nations. The programme would expose the community on the importance of saving water, the negative impacts of water scarcity as well as educate the community on the sustainable management of clean water for the betterment of the current and future generation. Other than that, posters and stickers about water saving should be distributed and made available in each compound in USM (eg: toilet, laundry room, pantry, etc.) as a reminder to USM community to save water whenever they consume water.

\section{Conclusion}

This research is conducted to assess USM students' water consumption at laundry rooms in two hostels as well as to assess their practices towards water conservation. This research measured the water meter readings in two USM hostels which consist of nine blocks in total for two 
consecutive weeks. This research has also distributed a set of questionnaire to 214 respondents who study and stay in the campus. Based on the water metre reading and questionnaire conducted in USM, the research found that on average, approximately 28,000 litres of water have been used for cloth washing daily. $82 \%$ of the respondents use washing machine to wash their loads which caused the excessive amount of water usage in the said hostels. The findings concluded that the level of awareness towards water conservation is still scarce among the students. It is suggested that more initiatives with greater impacts should be established by the university in order to expose the students to the staggering water shortage problem faced nationally and globally. The state government needs to play its roles by imposing stern law in order to ensure that water sustainability is well taken care of by the public, for instance introducing incentives to agencies that recycle water for non-potable use (Chan, 2004). This would encourage the university to take appropriate actions to manage water consumption sustainability such as installing water related appliances and equipment that consume less water such as front-load washing machine; which uses seven gallons of water per average load as compared to top-load washing machine (Janeway, 2017), faucet aerators, and rainwater harvester in all buildings within the campus (Chan, 2012).

Further research shall be conducted to review, compare, and contrast several water related awareness programmes that have been successfully conducted by other agencies which are suitable and would give greater impacts to the students in USM. This is because based on the result of water metre reading and questionnaire, the current awareness programmes mentioned on the previous section are not ample to change the students' behaviour and habit in managing water more sustainably. These said efforts would help the university to reduce its water consumption from time to time. Furthermore, by creating the consciousness towards prudent water consumption within the campus ecosystem, the community in USM would be more vigilant in conserving water to address water shortage problem nationally and globally for a better tomorrow.

\section{References}

Abdullah, N. (2015). Malaysians need to reduce water consumption. Retrieved December 12, 2018, from https://www.malaysiakini.com/letters/323856

Nagappan, B., \& Mathews, J. (2015). Energy and Water Consumption Analysis of Washing Process in a Fully Automatic Washing Machine. International Journal of Engineering Research, 10(11), 10341-10344. doi:10(11):10341-10344

Bernama. (2016). Malaysians 'overuse' water: Ongkili. New Strait Times. Retrieved September 13, 2018, from https://www.nst.com.my/news/2016/01/124927/malaysians-overuse-waterongkili

Chan, N. W. (2004). A Critical Review of Malaysia's Accomplishment on Water Resources Management Under AGENDA 21. Malaysian Journal of Environmental Management 5 (2004): 55 - 78. Retrieved from http://journalarticle.ukm.my/2197/1/2004_4_ChanNW.pdf on 2 August 2019 Chan, N. W. (2012). Transforming School of Humanities University Sains Malaysia into an Example 
INTERNATIONAL JOURNAL OF ACADEMIC RESEARCH IN PROGRESSIVE EDUCATION AND DEVELOPMENT

Vol. 8, No. 2, 2019, E-ISSN: 2226-6348 C 2019 HRMARS

of a Best Management Practice in Water Demand. 2012 International Conference on Environment, Chemistry and Biology IPCBEE vol.49 (2012) (C) (2012) IACSIT Press, Singapore. DOI: 10.7763/IPCBEE. 2012. V49. 32

Janeway, K. (2017). Yes, Your Washing Machine Is Using Enough Water. Retrieved August 2, 2019, from https://www.consumerreports.org/washing-machines/yes-your-washing-machineis-using-enough-water/

Fresh Water Watch. (n.d.). Water: A Limited Resource? Retrieved September 13, 2017, from https://freshwaterwatch.thewaterhub.org/content/water-limited-resource

Hermoso, V., Abell, R., Linke, S., and Boon, P. (2016). The role of protected areas for freshwater biodiversity conservation: challenges and opportunities in a rapidly changing world. Aquatic Conserv: Mar. Freshw. Ecosyst., 26: 3-11. doi: 10.1002/aqc.2681.

United Nations. (n.d ). Sustainable Development Goals (SDGs). Retrieved 13 September 2017 from http://www.un.org/sustainabledevelopment/sustainabledevelopment-goals/

USGS. (2016). The USGS Water Science School: How much water is there on, in, and above the Earth? Retrieved from https://water.usgs.gov/edu/earthhowmuch.html on 13

September 2017.

USM Sustainability Committee. (n.d). USM-APEX Sustainability Roadmap.

White, G. F. (1993). Water Crisis - A Guide to World Freshwater Resources. Retrieved 13 September 2017 from https://www.2000litergesellschaft.ch/fileadmin/user_upload/Referenzen_und_Literatur/ GLEICK_1993_Water_in_Crisis.pdf on.

Penang Water Supply Corporation (2017). Withdrawal of water tariff review is not an issue.

[Press release]. Retrieved from 30 December 2017 from http://www.pba.com.my/pdf/news/2017/27072017_Withdrawn_Tariff_Proposal_Nonlss ue_BM.pdf 